\title{
Glutathione Treatment Protects the Rat Liver against Injury after Warm Ischemia and Kupffer Cell Activation
}

\author{
Manfred Bilzer ${ }^{a}$ Andreas Baron ${ }^{a}$ Rolf Schauer ${ }^{b}$ Christian Steib ${ }^{a}$ \\ Stefan Ebensberger ${ }^{a}$ Alexander L. Gerbes ${ }^{a}$ \\ aDepartment of Medicine II and ' ${ }^{2}$ Surgical Department, Klinikum Grosshadern, Ludwig Maximilian University of \\ Munich, Germany
}

\section{Key Words}

Antioxidants · Glutathione - Ischemia-reperfusion injury • Kupffer cells $\cdot$ Liver perfusion $\cdot$ Reactive oxygen species

\begin{abstract}
Background/Aim: The generation of reactive oxygen species by activated Kupffer cells (KC) may contribute to reperfusion injury of the liver during liver transplantation or resection. The aim of our present studies was to investigate (1) prevention of hepatic reperfusion injury after warm ischemia by administration of the antioxidant glutathione (GSH) and (2) whether GSH confers protection through influences on KC toxicity. Methods: Isolated perfused rat livers were subjected to $1 \mathrm{~h}$ of warm ischemia followed by 90 min of reperfusion without $(n=5)$ or with GSH or catalase ( $n=4-5$ each). Selective KC activation by zymosan $(150 \mu \mathrm{g} / \mathrm{ml})$ in continuously perfused rat livers was used to investigate KC-related liver injury. Results: Postischemic infusion of $0.1,0.5,1.0$ and $2.0 \mathrm{mM} \mathrm{GSH}$, but not $0.05 \mathrm{mM}$ GSH prevented reperfusion injury after warm ischemia as indicated by a marked reduction of sinusoidal LDH efflux by up to $83 \pm 13 \%$ (mean \pm SD; $\mathrm{p}<0.05$ ) and a concomitant significant improvement of postischemic bile flow by $58 \pm 27 \%(p<0.05)$. A similar protection was conveyed by KC blockade with gadolinium chloride indicating prevention of KC-related reperfu-
\end{abstract}

sion injury by postischemic GSH treatment. Postischemic treatment with catalase $(150 \mathrm{U} / \mathrm{ml})$ resulted in a reduction of LDH efflux by $40 \pm 9 \%(p<0.05)$. Accordingly, catalase as well as GSH $(0.1-2.0 \mathrm{mM})$ nearly completely prevented the increase in LDH efflux following selective KC activation by zymosan in continously perfused rat livers. Conclusion: Postischemic administration of GSH protects the liver against reperfusion injury after warm ischemia. Detoxification of KC-derived hydrogen peroxide seem to be an important feature of the protective mechanisms.

Copyright (C2002 S. Karger AG, Basel

\section{Introduction}

Warm hepatic ischemia-reperfusion injury (IRI) occurs during surgical resections, liver transplantation, and hemorrhagic shock [1-3]. This can lead to liver damage, and in severe cases, to systemic organ dysfunction [3, 4]. Establishing blood flow to the liver as early as possible minimizes ischemic injury. Additional damage occurs during reperfusion [3,5]. A large body of evidence has been accumulated for the impact of reactive oxygen species (ROS) on reperfusion injury [6] and for Kupffer cells (KC) as the major source of ROS formation [7]. However, their involvement as direct toxic mediators was recently

\begin{tabular}{ll}
\hline KARGER & ( ) 2002 S. Karger AG, Basel \\
Fax +4161306 1234 & \\
$\begin{array}{l}\text { E-Mail karger@karger.ch } \\
\text { www.karger.com }\end{array}$ & $\begin{array}{l}\text { Accessible online at: } \\
\text { www.karger.com/journals/dig }\end{array}$
\end{tabular}

Manfred Bilzer, MD

Department of Medicine II

Klinikum Grosshadern, University of Munich

D-81377 Munich (Germany)

Tel. +49 897095 3183, Fax +49 897095 2392, E-Mail manfred.bilzer@t-online.de 
questioned [8,9]. Evidence now suggests that ROS act by influencing signal transduction processes rather than being directly involved in cell killing; they induce the activation of extracellular regulated kinases $[10,11]$ and redoxsensitive transcription factors [12-14] as well as the release of tumor necrosis factor and interleukins [15]. Furthermore, ROS have been implicated in microcirculatory failure after warm and cold ischemia [16-20]. Thus, ROS induce several pivotal mechanisms of cell injury suggesting a key role for ROS in the pathogenesis of reperfusion injury. This concept warrants antioxidative strategies to prevent reperfusion injury of the liver. This view is further supported by in vivo experiments showing protective effects of several antioxidants such as desferrioxamine [21], superoxide dismutase (SOD) [22, 23], dimethyl sulfoxide [24], and precursors of glutathione such as glutathione (GSH)-ethyl ester [25] and $N$-acetylcysteine [26, 27]. However, $N$-acetylcysteine failed to protect during human liver transplantation [28], whereas the use of the other antioxidants is limited by high costs and side effects. In order to develop a cost-effective antioxidant therapy without serious adverse effects recent studies focused on the cytoprotective potential of low molecular endogenous antioxidants, such as GSH. As demonstrated in models of isolated rat liver perfusion and rat liver transplantation, a high dose of GSH infusion during reperfusion protected against the reperfusion injury following $24 \mathrm{~h}$ of cold preservation in University of Wisconsin solution [29, 30].

The beneficial effects of GSH administration after cold liver preservation suggest a possible therapeutic potential in protecting the liver against injury caused by reperfusion after warm ischemia. However, reperfusion injury after warm ischemia differs in many aspects from preservation injury, e.g. the extent of $\mathrm{KC}$ activation and pattern of parenchymal and nonparenchymal cell damage [1-3]. Therefore, it remains speculative whether administration of GSH protects the liver against reperfusion injury after warm ischemia.

Several in vivo studies demonstrated oxidation of plasma GSH during reperfusion which was related in part to the detoxification of KC-derived ROS [7, 31]. Therefore, it was hypothesized that extracellular GSH may protect liver cells against the vascular oxidant stress by activated KC. Due to a possible interference with ROS of other sources in vivo, such as accumulating neutrophils [31] and xanthine oxidase released into the circulation [32], direct evidence for a reduction of KC-related oxidant liver injury by GSH is still lacking. Furthermore, it has not been investigated whether protective effects of high dose GSH treatment are related to a suppression of KC func- tion. This aspect seems to be of particular interest since antioxidative therapies should ideally protect liver cells against the inflammatory response of $\mathrm{KC}$ without impairing the vital host defense function of these cells.

Thus, the aim of our investigation was to study prevention of reperfusion injury after warm ischemia by GSH and the mechanisms involved. The effect of GSH on reperfusion injury was studied in isolated perfused rat livers subjected to $1 \mathrm{~h}$ of warm ischemia. The release of lactate dehydrogenase (LDH), as well as bile flow, were determined as parameters of cell damage and of liver function, respectively $[33,34]$. In a second set of experiments, we investigated the effect of GSH treatment on cell injury following $\mathrm{KC}$ activation in perfused rat livers. This model allows the selective investigation of KC-derived liver injury in the absence of ischemic injury or concomitant effects from neutrophils and extrahepatic macrophages $[35,36]$. Using this experimental model, we studied the effect of GSH administration on KC function by determination of zymosan particle phagocytosis and the stimulation of glycogenolysis by KC-derived eicosanoids [35].

\section{Materials and Methods}

\section{Isolated Perfused Rat Liver}

Male Sprague-Dawley rats (SAVO, Kisslegg, Germany) between 250 and $300 \mathrm{~g}$ were maintained under a 12-hour light/dark regimen with free access to a standard diet (Altromin 1314, Altromin, Lage, Germany) and water. The animals were anesthetized with an intraperitoneal injection of sodium pentobarbital $(50 \mathrm{mg} / \mathrm{kg}$ body weight $)$. The livers were perfused in situ after cannulation of the portal vein and hepatic veins via the right atrium and superior vena cava, respectively. The livers were perfused with hemoglobin-free and albumin-

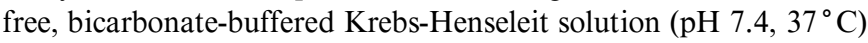
gassed with $95 \% \mathrm{O}_{2}$ and $5 \% \mathrm{CO}_{2}$ [37]. The Krebs-Henseleit buffer contained (in $\mathrm{m} M$ ) $118 \mathrm{NaCl}, 4.8 \mathrm{KCl}, 1.2 \mathrm{KH}_{2} \mathrm{PO}_{4}, 1.2 \mathrm{MgSO}_{4} \times 7$ $\mathrm{H}_{2} \mathrm{O}, 1.5 \mathrm{CaCl}_{2}$, and $25 \mathrm{NaHCO}_{3}$. The perfusion medium was pumped through the liver with a membrane pump at a constant flow rate of 3.0-3.5 $\mathrm{ml} \times \mathrm{min}^{-1} \times \mathrm{g}^{-1}$ liver in a nonrecirculating fashion. The bile duct was cannulated with PE-10 tubing, and bile was collected in preweighed tubes. Portal perfusion pressure was monitored manometrically from tubing attached to the inflow cannula [38]. The study was registered with the local animal welfare committee.

Rat livers which were continuously perfused for $120 \mathrm{~min}(\mathrm{n}=6)$ served as a control group for livers subjected to ischemia-reperfusion or KC activation.

\section{Warm Ischemia-Reperfusion of Rat Livers}

After cannulation of the portal vein livers were perfused for $30 \mathrm{~min}$. Thereafter, the perfusion flow was turned off for $60 \mathrm{~min}$ to produce warm ischemia $\left(30^{\circ} \mathrm{C}\right)$. During ischemia the livers were covered with wet gaze to avoid drying [33]. The temperature during ischemia was kept constant by means of a heating lamp. After $60 \mathrm{~min}$ 
of ischemia the perfusion was continued for another 90 min using preischemic flow rates.

Seven groups ( $n=4-5$ each) were subjected to warm ischemiareperfusion as follows:

(1) untreated; $30 \mathrm{~min}$ of perfusion, $60 \mathrm{~min}$ of ischemia, and reperfusion for $90 \mathrm{~min}$;

(2) gadolinium chloride; gadolinium chloride dissolved in saline solution $(0.9 \%)$ was administered intraperitoneally $(10 \mathrm{mg} / \mathrm{kg}$ body weight) 48 and $24 \mathrm{~h}$ before the experiments. Pretreated livers were subjected to $30 \mathrm{~min}$ of perfusion, $60 \mathrm{~min}$ of ischemia and $90 \mathrm{~min}$ of reperfusion.

(3-7) $0.05 \mathrm{mM}, 0.1 \mathrm{mM}, 0.5 \mathrm{mM}, 1.0 \mathrm{mM}$, or $2.0 \mathrm{mM} \mathrm{GSH}$, respectively; $30 \mathrm{~min}$ of perfusion, $60 \mathrm{~min}$ of ischemia, and reperfusion with administration of $0.05 \mathrm{~m} M, 0.1 \mathrm{~m} M, 0.5 \mathrm{~m} M, 1.0 \mathrm{~m} M$, or $2.0 \mathrm{~m} M$ GSH during the complete reperfusion period;

(8) catalase $(150 \mathrm{U} / \mathrm{ml}) ; 30 \mathrm{~min}$ of perfusion, $60 \mathrm{~min}$ of ischemia, and administration of catalase $(150 \mathrm{U} / \mathrm{ml})$ during the complete reperfusion period.

GSH (Sigma Chemical Co., St. Louis, Mo., USA) was dissolved in water. Because GSH is a weak acid, stock solutions of GSH were adjusted to a $\mathrm{pH}$ of 6.5 with $1 \mathrm{~N} \mathrm{NaOH}$ [29]. Stock solutions of catalase (Boehringer, Germany) were prepared in $0.9 \% \mathrm{NaCl}$. Stock solutions of GSH and catalase were infused into the portal inflow of the perfusion system by micro-infusion pumps.

\section{Liver Injury by Activated KC}

Activation of $\mathrm{KC}$ was induced by the infusion of zymosan to continuously perfused rat livers. Zymosan (Sigma Chemical Co., St. Louis, Mo., USA) consists of cell wall particles from yeast which are selectively taken up by KC [35]. Prior to infusion, zymosan suspensions were incubated at $95^{\circ} \mathrm{C}$ for $30 \mathrm{~min}$ to destroy activity of endogenous phospholipase $\mathrm{A}_{2}$ [35].

Seven groups $(n=4-7$ each) of zymosan-treated livers were studied:

(1) zymosan; administration of zymosan $(150 \mu \mathrm{g} / \mathrm{ml})$ from 40 to 46 min after starting perfusion $(\mathrm{n}=7)$;

(2-6) zymosan plus $0.05 \mathrm{mM}, 0.1 \mathrm{mM}, 0.5 \mathrm{mM}, 1.0 \mathrm{mM}$ or $2.0 \mathrm{mM} \mathrm{GSH}$; administration of zymosan from 40 to $46 \mathrm{~min}$ and of $0.05 \mathrm{~m} M, 0.1 \mathrm{~m} M, 0.5 \mathrm{~m} M, 1.0 \mathrm{~m} M$ or $2.0 \mathrm{~m} M$ GSH from 30 to $100 \mathrm{~min}$;

(7) zymosan plus catalase $(150 \mathrm{U} / \mathrm{ml})$; administration of zymosan from 40 to $46 \mathrm{~min}$ and of catalase $(150 \mathrm{U} / \mathrm{ml})$ from 30 to $100 \mathrm{~min}$.

\section{Analytical Methods}

Sinusoidal efflux of LDH was measured as an index of liver cell damage $[33,37]$. The activities of LDH released into the perfusate were analyzed according to standard tests [39]. Postischemic liver function was assessed from recovery of bile flow [34]. The content of total GSH (reduced and oxidized fraction) in shock frozen liver samples was measured by the enzymatic recycling test using GSH reductase and 5,5'-dithio-bis-(2-nitrobenzoic acid) [40, 41]. Uptake of zymosan was used as an indicator of particle phagocytosis by $\mathrm{KC}$. Zymosan uptake was assessed by the difference in absorbance of the inflow and outflow perfusion buffer at $540 \mathrm{~nm}$ [35]. Sinusoidal efflux of glucose was determined according to standard tests [39].

\section{Statistics}

All data are expressed as the mean \pm standard deviation (SD). Statistical significance between the control group and a treated group was determined with Student's t-test of independent means. Com- parisons between multiple groups were performed using one-way analysis of variance (ANOVA); when F ratios were significant, means were compared using Bonferroni's test as the post hoc comparison. A $\mathrm{p}$ value of 0.05 or below was considered statistically significant. The statistical analyses were performed with SPSS software, release 6.1.3 (SPSS Inc., Chicago, Ill., USA).

\section{Results}

\section{Effect of GSH on Liver Injury after Warm Ischemia}

Cell damage was assessed by sinusoidal efflux of LDH. Perfusion of rat livers in a continuous fashion resulted in low LDH efflux rates which increased to only $40 \pm$ $34 \mathrm{mU} / \mathrm{min} \times \mathrm{g}$ liver at the end of the 2-hour perfusion period (fig. 1). When livers were subjected to $60 \mathrm{~min}$ of warm ischemia, considerable cell damage occured during reperfusion (fig. 1). LDH efflux increased rapidly within $60 \mathrm{~min}$ of reperfusion reaching $774 \pm 232 \mathrm{mU} / \mathrm{min} \times$ g liver at $90 \mathrm{~min}$ (total perfusion time $2 \mathrm{~h}$ ) (fig. 1). This cell damage was attenuated by KC blockade with gadolinium chloride as indicated by the significant $(\mathrm{p}<0.05)$ reduction of LDH efflux to only $82 \pm 53 \mathrm{mU} / \mathrm{min} \times \mathrm{g}$ liver at $90 \mathrm{~min}$ of reperfusion. Similar cytoprotective effects were observed with $0.5,1.0$ and $2.0 \mathrm{~m} M \mathrm{GSH}$, but not with 0.05 and $0.1 \mathrm{~m} M$ GSH (fig. 1, table 1). When livers were reperfused with catalase $(150 \mathrm{U} / \mathrm{ml}) \mathrm{LDH}$ efflux declined to $450 \pm 93 \mathrm{mU} / \mathrm{min} \times \mathrm{g}$ liver which was significantly $(\mathrm{p}<0.05)$ more than in livers treated with $0.5,1.0$ and $2.0 \mathrm{~m} M$ GSH (table 1).

Bile flow of continuously perfused livers significantly decreased from $1.18 \pm 0.15 \mu \mathrm{l} / \mathrm{min} \times \mathrm{g}$ liver initially to $0.66 \pm 0.09 \mu \mathrm{l} / \mathrm{min} \times \mathrm{g}$ liver at $2 \mathrm{~h}(\mathrm{p}<0.05$; fig. 2$)$. A significantly lesser bile flow was found in livers subjected to warm ischemia and reperfusion. Postischemic bile flow of the untreated livers remained markedly reduced and returned to only $0.33 \pm 0.05 \mu \mathrm{l} / \mathrm{min} \times \mathrm{g}$ liver at the end of reperfusion (fig. 2). In contrast, pretreatment with gadolinium chloride significantly $(\mathrm{p}<0.05)$ increased bile flow to $0.58 \pm 0.07 \mu \mathrm{l} / \mathrm{min} \times \mathrm{g}$ liver. A similar improvement of bile flow to $0.52 \pm 0.09 \mu \mathrm{l} / \mathrm{min} \times \mathrm{g}$ liver was achieved by postischemic infusion of $2 \mathrm{~m} M$ GSH (fig. 2). Furthermore, bile flow was similarly improved by reperfusion with $0.1,0.5$ and $1.0 \mathrm{~m} M \mathrm{GSH}$, whereas $0.05 \mathrm{~m} M$ GSH failed to influence postischemic bile flow (table 1).

In contrast, reperfusion of livers with catalase did not affect postischemic bile flow (table 1).

In an attempt to investigate the potential mechanism of GSH-mediated protection, we investigated effects on portal pressure and intracellular GSH content. Portal pressure of continuously perfused livers was $3.7 \pm 0.4 \mathrm{~cm}$ 
Fig. 1. Effect of GSH on hepatic reperfusion injury after $1 \mathrm{~h}$ of warm ischemia. When livers were reperfused after $1 \mathrm{~h}$ of warm ischemia $(\bullet, n=5)$, LDH efflux markedly increased indicating considerable cell damage. Administration of $2.0 \mathrm{~m} M$ GSH during the 90-min reperfusion period $(\boldsymbol{\square} \mathrm{n}=5)$ significantly prevented LDH increase. For comparison, LDH release during $120 \mathrm{~min}$ of continuous perfusion is indicated $(\bullet-\downarrow, \mathrm{n}=$ 5). Mean \pm SD. $* p<0.05$ compared with untreated livers subjected to $1 \mathrm{~h}$ of warm ischemia $(\mathbf{O})$.

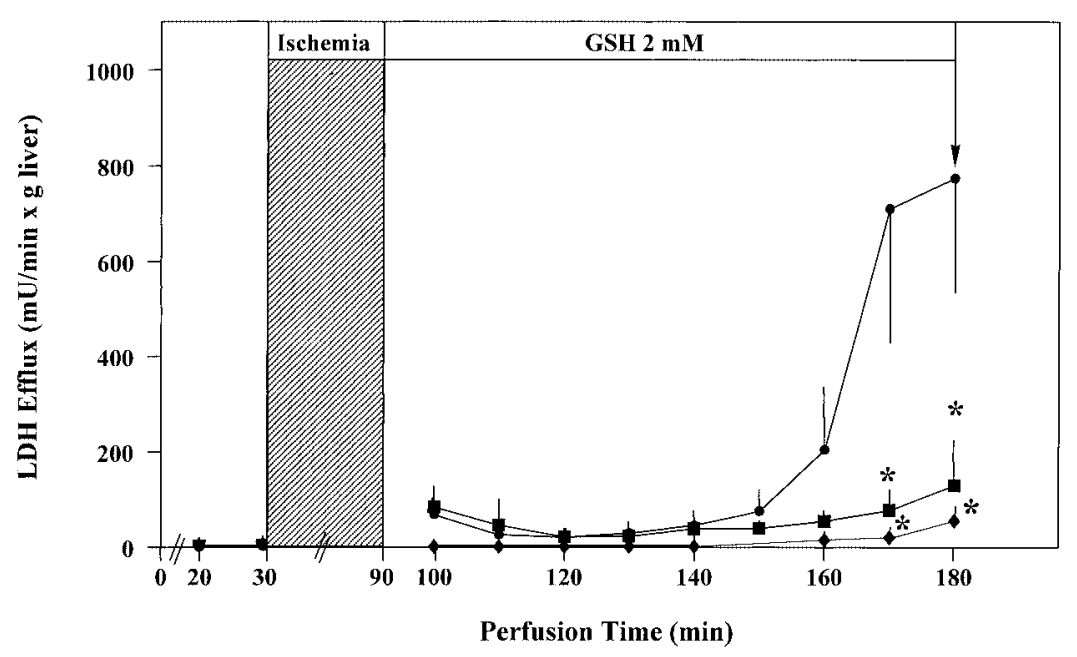

Table 1. Concentration-dependent effect of GSH on postischemic cell damage, bile flow, portal pressure, and intracellular GSH content after $1 \mathrm{~h}$ of warm ischemia and 90 min reperfusion

\begin{tabular}{llllll}
\hline & & $\begin{array}{l}\text { LDH efflux } \\
\mathrm{mU} / \mathrm{min} \times \mathrm{g} \text { liver }\end{array}$ & $\begin{array}{l}\text { Bile flow } \\
\mu \mathrm{l} / \mathrm{min} \times \mathrm{g} \text { liver }\end{array}$ & $\begin{array}{l}\text { Portal pressure } \\
\mathrm{cm} \mathrm{H}_{2} \mathrm{O}\end{array}$ & $\begin{array}{l}\text { Intracellular GSH } \\
\mu \text { mol/g liver }\end{array}$ \\
\hline Untreated & & $774 \pm 232$ & $0.33 \pm 0.05$ & $11.4 \pm 1.7$ & $6.8 \pm 1.0$ \\
$\mathrm{GSH}$ & $0.05 \mathrm{~m} M$ & $560 \pm 189$ & $0.45 \pm 0.13$ & $12.1 \pm 2.5$ & $8.2 \pm 0.7$ \\
& $0.1 \mathrm{~m} M$ & $299 \pm 126$ & $0.54 \pm 0.07^{\mathrm{a}}$ & $10.1 \pm 1.8$ & $7.3 \pm 0.9$ \\
& $0.5 \mathrm{~m} M$ & $130 \pm 53^{\mathrm{a}}$ & $0.57 \pm 0.15^{\mathrm{a}}$ & $11.1 \pm 2.5$ & $8.0 \pm 0.9$ \\
& $1.0 \mathrm{~m} M$ & $139 \pm 74^{\mathrm{a}}$ & $0.49 \pm 0.15^{\mathrm{a}}$ & $10.7 \pm 1.4$ & $7.9 \pm 0.9$ \\
& $2.0 \mathrm{~m} M$ & $129 \pm 98^{\mathrm{a}}$ & $0.52 \pm 0.09^{\mathrm{a}}$ & $11.7 \pm 3.2$ & $8.4 \pm 0.7$ \\
Catalase & $150 \mathrm{U} / \mathrm{ml}$ & $450 \pm 93^{\mathrm{a}, \mathrm{b}}$ & $0.29 \pm 0.04$ & $10.5 \pm 1.6$ & $7.1 \pm 0.8$ \\
\hline
\end{tabular}

Livers were perfused for $30 \mathrm{~min}$ and then subjected to $60 \mathrm{~min}$ of warm ischemia. Sinusoidal efflux rates of LDH, bile flow, and the intracellular GSH content were estimated after $90 \mathrm{~min}$ of reperfusion. Maximal portal pressure during reperfusion was achieved after 2 min of reperfusion. Livers were perfused in the absence (untreated; $n=5$ ) or presence of different GSH concentrations (each $n=4-5$ ). Data are expressed as mean \pm SD.

${ }^{\mathrm{a}} \mathrm{p}<0.05$ compared with untreated livers; ${ }^{\mathrm{b}} \mathrm{p}<0.05$ compared with $0.5,1.0$ and $2.0 \mathrm{~m} M \mathrm{GSH}$.

$\mathrm{H}_{2} \mathrm{O}$ and remained stable during the 2-hour perfusion period. In contrast, portal pressure increased immediately after starting reperfusion reaching a maximum of $11.4 \pm$ $1.7 \mathrm{~cm} \mathrm{H} \mathrm{H}_{2} \mathrm{O}$ within 2 min (table 1). During further reperfusion, portal pressure decreased and returned to baseline after 20 min (data not shown). Administration of GSH at any tested concentrations as well as of catalase neither affected the maximal increase of portal pressure (table 1) nor the return to baseline (data not shown).

At the end of the reperfusion period, the intracellular glutathione content (sum of GSH and GSSG) of untreated livers was determined at $6.8 \pm 1.0 \mu \mathrm{mol} / \mathrm{g}$ liver. Postischemic treatment with $2.0 \mathrm{~m} M$ GSH did not affect the intracellular glutathione content to $8.4 \pm 0.7 \mu \mathrm{mol} / \mathrm{g}$ liver. However, a similar not significant increase was observed at other concentrations, in particular with $0.05 \mathrm{~m} M \mathrm{GSH}$, that showed no cytoprotection (table 1). Therefore, GSHmediated cytoprotection seemed not to be related to influences on the intracellular glutathione content. 
Fig. 2. Influence of GSH treatment on postischemic bile flow. During reperfusion bile flow of untreated livers $(\mathbf{Q}, n=5)$ remained significantly reduced when compared with continuously perfused livers $(\checkmark-\downarrow, n=5)$. Treatment with $2.0 \mathrm{~m} M$ GSH $(\mathbf{\square}, \mathrm{n}=5)$ significantly increased postischemic bile flow but did not provide complete recovery. Mean \pm SD. ${ }^{*} \mathrm{p}<0.05$ compared with untreated livers subjected to $1 \mathrm{~h}$ of warm ischemia.

Table 2. Influence of different GSH concentrations on cell damage and bile flow following $\mathrm{KC}$ activation

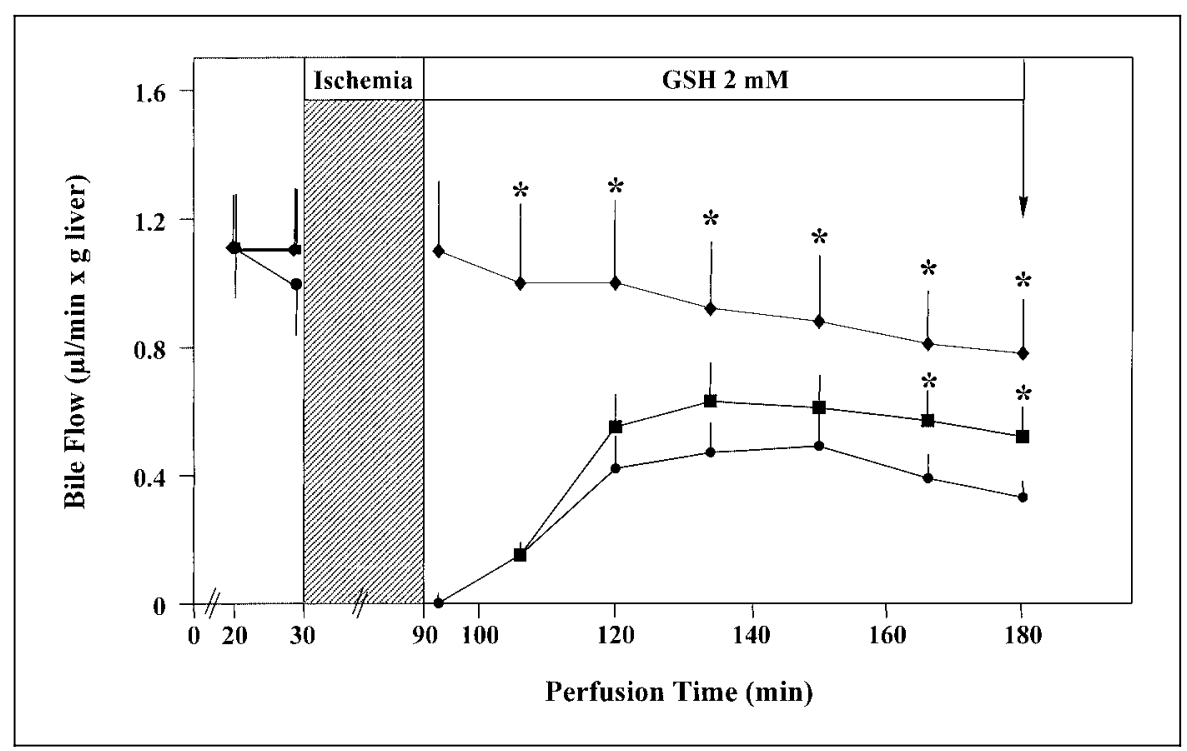

\begin{tabular}{llll}
\hline & & $\begin{array}{l}\text { LDH efflux } \\
\mathrm{mU} / \mathrm{min} \times \mathrm{g} \text { liver }\end{array}$ & $\begin{array}{l}\text { Bile flow } \\
\mu \mathrm{l} / \mathrm{min} \times \mathrm{g} \text { liver }\end{array}$ \\
\hline Zymosan & & $56 \pm 25$ & $0.60 \pm 0.15$ \\
Zymosan plus GSH & $0.05 \mathrm{~m} M$ & $41 \pm 11$ & $0.60 \pm 0.07$ \\
& $0.1 \mathrm{~m} M$ & $21 \pm 10^{\mathrm{a}}$ & $0.62 \pm 0.08$ \\
& $0.5 \mathrm{~m} M$ & $15 \pm 6^{\mathrm{a}}$ & $0.64 \pm 0.35$ \\
& $1.0 \mathrm{~m} M$ & $20 \pm 14^{\mathrm{a}}$ & $0.60 \pm 0.09$ \\
Zymosan plus Catalase & $2.0 \mathrm{~m} M$ & $10 \pm 6^{\mathrm{a}}$ & $0.51 \pm 0.11$ \\
& $150 \mathrm{U} / \mathrm{ml}$ & $11 \pm 3^{\mathrm{a}}$ & $0.61 \pm 0.08$ \\
\hline
\end{tabular}

KC were activated by the administration of zymosan $(150 \mu \mathrm{g} / \mathrm{ml})$ from 40 to $46 \mathrm{~min}(\mathrm{n}=$ 7). GSH was infused at different concentrations from 30 to 100 min after starting perfusion (each group $\mathrm{n}=4-5$ ). Data represent LDH efflux and bile flow rates at $100 \mathrm{~min}$ of perfusion. Data are expressed as mean $\pm \mathrm{SD}$.

${ }^{a} \mathrm{p}<0.05$ compared to livers treated with zymosan only.

\section{Effect of GSH Administration on Liver Injury}

\section{following KC Activation}

$\mathrm{KC}$ of continuously perfused rat livers were activated by a 6 -minute infusion of zymosan $(150 \mu \mathrm{g} / \mathrm{ml})$. Sixty minutes after zymosan infusion was started LDH efflux markedly increased reaching $56 \pm 25 \mathrm{mU} / \mathrm{min} \times \mathrm{g}$ liver at the end of perfusion compared to only $4 \pm 2 \mathrm{mU} / \mathrm{min}$ $\times \mathrm{g}$ liver in untreated controls $(\mathrm{p}<0.05)$ (fig. 3$)$. When Kupffer cells were activated in the presence of $2.0 \mathrm{mM}$ GSH, sinusoidal LDH release increased to only $10 \pm$ $6 \mathrm{mU} / \mathrm{min} \times \mathrm{g}$ liver $(\mathrm{p}<0.05)$ (fig. 3$)$ indicating protection against Kupffer cell-related cell damage. Similar protective effects were observed with $0.1,0.5$ and $1.0 \mathrm{mM}$
GSH (table 2), but not with $0.05 \mathrm{~m} M$ GSH. Moreover, a comparable reduction of LDH efflux was achieved by treatment with catalase $(150 \mathrm{U} / \mathrm{ml})$ (fig. 3).

Following KC activation by zymosan, bile flow declined from initially $1.23 \pm 0.17$ to $0.60 \pm 0.15 \mu \mathrm{l} / \mathrm{min} \times$ $\mathrm{g}$ liver at the end of experiments (fig. 4). The decrease of bile flow was not different from that observed in untreated livers (fig. 4). In addition, bile flow of zymosantreated livers was neither affected by GSH nor by catalase (fig. 4, and table 2).

$\mathrm{KC}$ activation by zymosan resulted in a marked increase of sinusoidal glucose efflux (fig. 5) which reflects the stimulation of glycogenolysis by KC-derived eicasa- 
Fig. 3. Effect of GSH on liver cell damage following $\mathrm{KC}$ activation by zymosan. $\mathrm{KC}$ of continuously perfused rat livers were activated by infusion of zymosan $(150 \mu \mathrm{g} / \mathrm{ml})$ for $6 \min (\diamond, \mathrm{n}=7)$. Compared to zymosan-free perfused controls $(\boldsymbol{\Delta}, \mathrm{n}=6)$, LDH efflux rates significantly increased 40-60 min after KC activation. Treatment with $2.0 \mathrm{~m} M$ GSH $(\boldsymbol{\square}, \mathrm{n}=5)$, significantly reduced the zymosan-induced LDH efflux. Mean \pm SD. $* \mathrm{p}<0.05$ compared with livers treated with zymosan alone.

Fig. 4. Effect of GSH treatment on bile flow following $\mathrm{KC}$ activation. Compared to control livers $(\boldsymbol{\Lambda}, \mathrm{n}=6)$, bile flow was neither affected by the infusion of zymosan $(150 \mu \mathrm{g} /$ $\mathrm{ml})(\diamond, \mathrm{n}=7)$ nor by the concomitant infusion of $2.0 \mathrm{~m} M \mathrm{GSH}(\boldsymbol{\square}, \mathrm{n}=5)$. Mean \pm SD.

noids [35]. Infusion of $2 \mathrm{~m} M$ GSH showed no effect on zymosan-stimulated glucose release (fig. 5). These findings argue against a relevant inhibition of $\mathrm{KC}$ activation or function by GSH. This concept is further supported by the lack of effect on zymosan particle phagocytosis. When zymosan was infused to untreated livers $60 \pm 6 \%$ of administered particles were taken up. A similar zymosan uptake was observed in livers treated with $2 \mathrm{mM}$ (56 \pm $13 \%), 1 \mathrm{~m} M(50 \pm 16 \%)$ and $0.5 \mathrm{~m} M \mathrm{GSH}(60 \pm 14 \%)$.

\section{Discussion}

The findings of the present study clearly indicate a therapeutic potential of postischemic GSH treatment in protecting the liver against warm ischemia-reperfusion injury. A large body of evidence has been accumulated for the impact of ROS on reperfusion injury of the liver [6] and for $\mathrm{KC}$ as the major source of ROS formation [7, 42] suggesting a possible detoxification of KC-derived ROS by GSH.

Using the model of isolated rat liver perfusion we obtained the following main results: (1) increase of the extracellular GSH concentration upon reperfusion as well 
Fig. 5. Effect of GSH treatment on KCmediated glycogenolysis. Activation of $\mathrm{KC}$ by zymosan $(150 \mu \mathrm{g} / \mathrm{ml})(\diamond, \mathrm{n}=7)$ resulted in a significant increase of sinusoidal glucose release which was not affected by treatment with $2.0 \mathrm{~m} M$ GSH $(\boldsymbol{\square}, \mathrm{n}=5)$. Mean $\pm \mathrm{SD}$. $* \mathrm{p}<0.05$ compared with untreated controls $(\boldsymbol{\Delta}, \mathrm{n}=6)$.

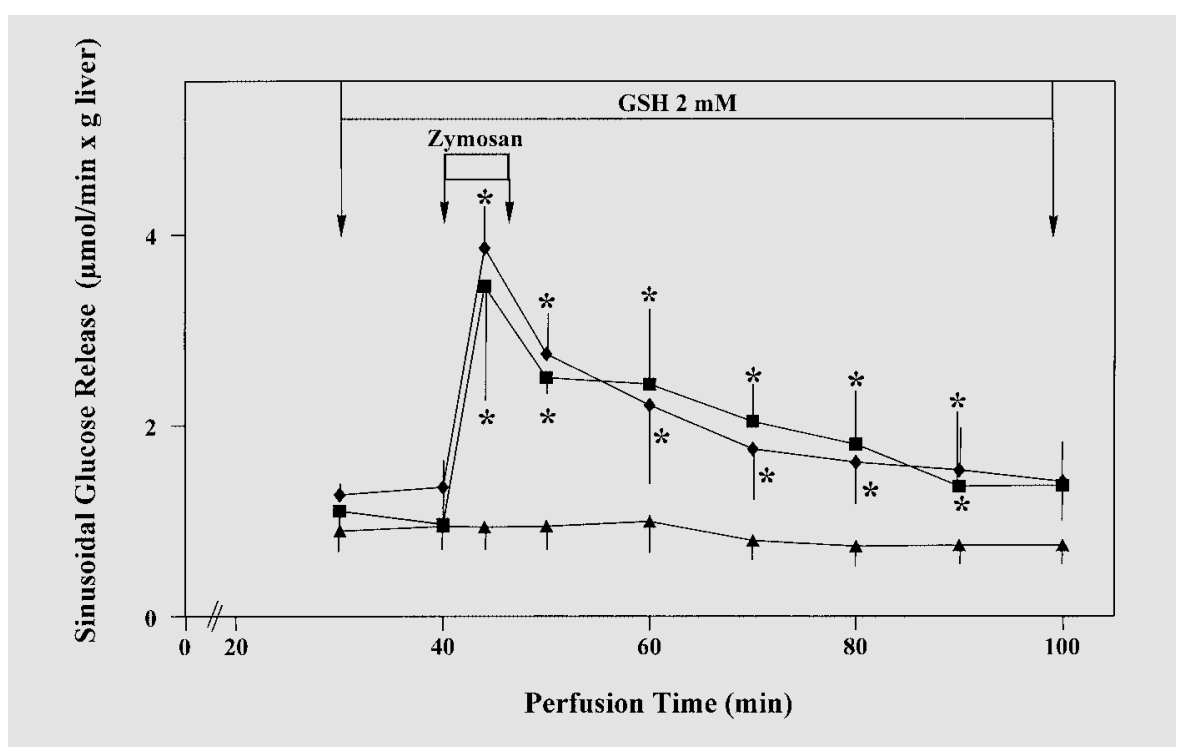

as $\mathrm{KC}$ blockade by gadolinium chloride causes significant reduction of reperfusion injury after $1 \mathrm{~h}$ of warm liver ischemia; (2) administration of GSH almost completely prevents liver injury following selective $\mathrm{KC}$ activation but does not influence KC function; (3) GSH treatment appears to reduce cell damage by KC-derived hydrogen peroxide $\left(\mathrm{H}_{2} \mathrm{O}_{2}\right)$ because treatment with catalase results in a similar prevention of $\mathrm{KC}$-induced cell injury.

\section{Prevention of Reperfusion Injury by Postischemic GSH Treatment}

Administration of GSH upon reperfusion reduced sinusoidal LDH efflux by approximately $80 \%$. This cytoprotective effect was accompanied by an improvement of liver function as assessed by a two fold increase of postischemic bile flow. In contrast, infusion of GSH to continuously perfused rat livers did not affect bile flow [29]. These findings argue against a choleretic effect of GSH that might mimick improved liver function. Therefore, increased bile flow most likely reflects improved liver function through GSH-mediated cytoprotection. Because postischemic GSH treatment can only protect liver cells which are not already seriously damaged before the onset of reperfusion, our results clearly demonstrate prevention of reperfusion injury by GSH.

Prevention of reperfusion injury by GSH depended on the concentration applied during reperfusion: $0.5,1.0$ and $2.0 \mathrm{~m} M$, but not 0.05 and $0.1 \mathrm{~m} M$, were effective. When rat livers were subjected to $1 \mathrm{~h}$ of warm ischemia in vivo plasma GSH increased to only 0.02 and $0.03 \mathrm{~m} M$ after 30 and $60 \mathrm{~min}$ of reperfusion, repectively [7]. This increase has been regarded as an endogenous defense mechanism in protecting liver cells from reperfusion injury [7]. In contrast, our experiments indicate cytoprotection only at GSH concentrations of at least $0.1 \mathrm{~m} M$. Therefore, it can be speculated that the increase of endogenous plasma GSH in vivo is not sufficient to prevent ROS-related reperfusion injury. This view is further supported by in vivo experiments showing protective effects of intravenously applied GSH [30] and several other antioxidants such as desferrioxamine [21] and SOD [22, 23].

GSH is not taken up by the liver at physiological plasma concentrations [43, 44], but GSH uptake into hepatocytes may occur at high (millimolar) extracellular concentrations [45]. Reperfusion of livers with GSH resulted in a slight, but not significant, increase of the intracellular GSH content in all treatment groups. In contrast, only GSH concentrations $>0.1 \mathrm{~m} M$ were protective. Thus, it seems unlikely that influences on intracellular GSH status contribute to cytoprotection by GSH treatment.

\section{Prevention of KC-Induced Oxidant Injury by GSH}

Activation of $\mathrm{KC}$ in vivo induces a complex network of cytokines accompanied by vascular inflammation [3-5]. Furthermore, there is evidence for a pivotal role of ROS in these pathophysiological events [5-7, 46]. In line with these observations our results clearly demonstrate that $\mathrm{KC}$ blockade by gadolinium chloride results in a nearly complete prevention of reperfusion injury in the model of isolated rat liver perfusion. Because gadolinium chloride 
and GSH treatment showed almost identical protective effects (reduction of LDH efflux by approximately $80 \%$ ) our results clearly demonstrate prevention of KC-mediated reperfusion injury by GSH. This interpretation is further substantiated by perfusion experiments allowing the selective activation of $\mathrm{KC}$ by infusion of zymosan. Using this experimental model $\mathrm{KC}$-induced cell damage was nearly completely reduced by the concomitant infusion of catalase. Catalase selectively detoxifies $\mathrm{H}_{2} \mathrm{O}_{2}$. Therefore, its protective effects indicate $\mathrm{H}_{2} \mathrm{O}_{2}$-mediated liver cell damage by activated $\mathrm{KC}$. Treatment of the liver with $0.5,1.0$ and $2.0 \mathrm{~m} M$ GSH protected from KC-related cell injury in a fashion similar to catalase. These findings strongly support detoxification of $\mathrm{H}_{2} \mathrm{O}_{2}$ by GSH. Because catalase and GSH are poorly taken up by liver cells their cytoprotective action seems to take place mainly in the extracellular space. This view is supported by earlier in vivo experiments which demonstrated a considerable oxidation of plasma GSH following KC activation [46, 47]. Thus, our results provide direct evidence for a pivotal role of extracellular GSH in protecting liver cells against the vascular oxidant stress produced by activated $\mathrm{KC}$.

Bile flow was neither affected by the activation of $\mathrm{KC}$ nor by the concomitant infusion of GSH. These findings suggest that activated $\mathrm{KC}$ do not contribute to the impairment of bile flow after warm or cold ischemia. In line with this interpretation, recent studies failed to demonstrate an effect on postischemic bile flow when $\mathrm{KC}$ were depleted prior to liver transplantation [20,48, 49]. On the other hand, we could demonstrate a significant improvement of postischemic bile flow in livers treated with gadolinium chloride. Further studies are necessary to adress these controversial effects of $\mathrm{KC}$ blockade after warm or cold ischemia.

In agreement with earlier experiments [35] KC activation by zymosan resulted in a marked increase of glycogenolysis as indicated by a severalfold increase of sinusoidal glucose efflux which has been attributed to the stimulation of glycogenolysis by KC-derived prostaglandins [35]. Prostaglandin-related effects thus can be regarded as a part of the inflammatory response of activated KC. However, there was no evidence for a possible modulation of prostaglandin production by GSH treatment because zymosan-stimulated glucose efflux was not influenced by the infusion of GSH. Therefore, protective effects of GSH seem not to be related to influences on $\mathrm{KC}$ activation or $\mathrm{KC}$ function. This contention is further supported by the lack of effect of GSH treatment on zymosan particle phagocytosis. In contrast, other protective approaches such as the depletion of $\mathrm{KC}$ by dichlormethylene diphosphonate [48] or gadolinium chloride [7, 20,28] as well as KC-blockade by calcium antagonists [17] impair the vital host defense function of KC. Based on our findings, these problems can be avoided by direct infusion of GSH.

In conclusion, administration of GSH can be considered as a new pharmacological approach to prevent KCdependent and $\mathrm{KC}$-independent reperfusion injury of the liver after warm ischemia. In view of this therapeutic potential and the apparent absence of untoward side effects in humans following high-dose intravenous GSH infusion [50], clinical trials can be conducted to evaluate the therapeutic potential of GSH during human liver transplantations and liver resections.

\section{Acknowledgments}

The authors thank A. Hertle and I. Liß for excellent technical assistance.

This work was supported in part by grants from the Friedrich Baur Stiftung and the Deutsche Forschungsgemeinschaft (DFG Ge 576/14-1 and DFG Scha 857/1-1). Parts of this study were presented at the 50th Annual Meeting of the American Association for the Study of Liver Diseases, November 5-9, 1999, Dallas.

\section{References}

1 Clavien PA, Harvey PRC, Strasberg SM: Preservation and reperfusion injuries in liver allografts. Transplantation 1992;53:957-978.

2 Lemasters JJ, Bunzendahl H, Thurman RG: Reperfusion injury to donor livers stored for transplantation. Liver Transplant Surg 1995;1: 124-138.

3 Jaeschke H: Preservation injury: mechanisms, prevention and consequences. J Hepatol 1996; 25:774-780.
4 Wanner GA, Ertel W, Müller P, Höfer Y, Leiderer R, Menger MD, Messmer K: Liver ischemia and reperfusion induces a systemic inflammatory response through Kupffer cell activation. Shock 1996;5:34-40.

5 Bilzer M, Gerbes AL: Preservation injury of the liver: Mechanisms and novel therapeutic strategies. J Hepatol 2000;32:508-515.

6 Jaeschke H: Reactive oxygen and ischemia/ reperfusion injury of the liver. Chem Biol Interact 1991;79:115-136.
7 Jaeschke H, Farhood A: Neutrophil and Kupffer cell-induced oxidant stress and ischemiareperfusion injury in rat liver. Am J Physiol 1991;260:G355-G362.

8 Mathews WR, Guido DM, Fischer MA, Jaeschke H: Lipid peroxidation as molecular mechanism of liver injury during reperfusion after ischemia. Free Radical Biol Med 1994;16: 763-770. 
9 Brass CA, Nunes F, Nagpal R: Increased oxyradical production during reoxygenation of perfused rat liver. Signal versus injury. Transplantation 1994;58:1329-1335.

10 Guyton KZ, Liu Y, Gorospe M, Xu Q, Holbrook N: Activation of mitogen-activated kinase by $\mathrm{H}_{2} \mathrm{O}_{2}$. J Biol Chem 1996;271:41384142 .

11 Bradham CA, Stachlewitz RF, Gao W, Qian T, Jayadev S, Jenkins G, et al: Reperfusion after liver transplantation differentially activates the mitogen-activated protein kinases. Hepatology 1997;25:1128-1135.

12 Baeuerle PA, Henkel T: Function and activation of NF- $\mathrm{BB}$ in the immune system. Ann Rev Immunol 1994;12:2956-2963.

13 Essani NA, McGuire GM, Manning AM, Jaeschke H: Endotoxin-induced activation of the nuclear transcription factor $\kappa \mathrm{B}$ in in hepatocytes, Kupffer cells and endethelial cells in vivo. J Immunol 1996;156:2956-2963.

14 Gerbes AL, Vollmar AM, Kiemer AK, Bilzer M: The guanylate cyclase-coupled natriuretic peptide receptor: A new target for prevention of cold ischemia-reperfusion damage of the rat liver. Hepatology 1998;28:1309-1317.

15 Le Moine O, Luis H, Stordeur P, Collet J-M, Goldman M, Deviere J: Role of reactive oxygen intermediates in interleukin-10 release after cold liver ischemia and reperfusion in mice. Gastroenterology 1997;113:1701-1706.

16 Koo A, Komatsu H, Tao G, Inoue M, Guth $\mathrm{PH}$, Kaplowitz N: Contribution of no-reflow phenomenon to hepatic injury after ischemiareperfusion: Evidence for a role for superoxide anion. Hepatology 1992;15:507-514.

17 Marzi I, Walcher F, Buehren V: Macrophage activation and leukocyte adhesion after liver transplantation. Am J Physiol 1993;265: G172-G177.

18 Schauer RJ, Bilzer M, Kalmuk S, Gerbes AL, Schildberg FW, Messmer K: Oxidized plasma glutathione: An indicator of microcirculatory failure after hypothermic liver preservation? Transplantation 2001; in press.

19 Bilzer M, Lauterburg BH: Effects of hypochlorous acid and chloramines on vascular resistance, cell integrity, and biliary glutathione disulfide in the perfused rat liver: Modulation by glutathione. J Hepatol 1991;13:84-89.

20 Bilzer M, Gerbes AL: Prolonged modulation of the hepatic circulation by Kupffer cell-derived reactive oxygen species; in: Wisse E, Knook DL, Balabaud C (eds): Cells of the Hepatic Sinusoid. Leiden, Kupffer Cell Foundation, 1996 vol 6, pp 200-201.

21 Drugas GT, Paidas CN, Yahanda AM, Ferguson D, Clemens MG: Conjugated desferrioxamine attenuates hepatic microvascular injury following ischemia/reperfusion. Circ Shock 1991;34:278-283.
22 Kawamoto S, Inoue M, Tashiro S, Morino Y, Miyauchi Y: Inhibition of ischemia and reflowinduced liver injury by an SOD derivate that circulates bound to albumin. Arch Biochem Biophys 1990;277:160-165.

23 Kobayashi H, Nonami T, Kurokawa T, Sugiyama S, Ozawa T, Tagaki H: Mechanism and prevention of ischemia-reperfusion-induced liver injury in rats. J Surg Res 1991;51:240-244.

24 Essani NA, Fischer MA, Jaeschke H: Inhibition of NF- $\kappa \mathrm{B}$ activation by dimethyl sulfoxide correlates with supppression of $\mathrm{TNF} \alpha$ formation, reduced ICAM-1 gene transcription, and protection against endotoxin-induced liver injury. Shock 1997;7:90-96.

25 Kobayashi H, Kurokawa T, Kitahara S, Nonami T, Harada A, Nakao A, Sugiyama S, Ozawa T, Takagi H: The effects of $\gamma$-glutamylcysteine ethyl ester, a prodrug of glutathione, on ischemia-reperfusion-induced liver injury in rats. Transplantation 1992;54:414-418.

26 Dunne JB, Davenport M, Williams R, Tredger JM: Evidence that $S$-adenosylmethionine and $\mathrm{N}$-acetylcysteine reduce injury from sequential cold and warm ischemia in the isolated perfused rat liver. Transplantation 1994;57:11611168.

27 Nakano H, Boudjema K, Alexandre E, Imbs P, Chenard MP, Wolf P, Cinqualbre J, Jaeck D: Protective effects of $N$-acetylcysteine on hypothermic ischemia-reperfusion injury of rat liver. Hepatology 1995;22:539-545.

28 Steib A, Freys G, Collin F, Launoy A, Mark G, Boudjema K: Does N-acetylcysteine improve hemodynamics and graft function in liver transplantation? Liver Transplant Surg 1998;4: 152-157.

29 Bilzer M, Paumgartner G, Gerbes AL: Glutathione protects the rat liver against reperfusion injury after hypothermic preservation. Gastroenterology 1999;117:200-210.

30 Schauer RJ, Kalmuk S, Gerbes AL, Messmer K, Schildberg FW, Bilzer M: Glutathione protects the liver against reperfusion injury after orthotopic transplantation in the rat. Hepatology 1999;30:225A.

31 Jaeschke H, Farhood A, Smith CW: Neutrophils contribute to ischemia/reperfusion injury in rat liver in vivo. FASEB J 1990;4:33553359 .

32 Weinbronn A, Nielsen VG, Tan S, Gelman S, Skinner KA, Bradley E jr, Parks DA: Liver ischemia and reperfusion increases pulmonary permeability in rat: Role of circulating xanhine oxidase. Am J Physiol 1995;268:G988-G996.

33 Bilzer M, Witthaut R, Paumgartner G, Gerbes AL: Prevention of ischemia/reperfusion injury in the rat liver by atrial natriuretic peptide. Gastroenterology 1994;106:143-151.

34 Bowers BA, Branum GD, Rotolo FS, Watters CR, Meyers WC: Bile flow - an index of ischemic injury. J Surg Res 1987;42:565-569.

35 Dieter P, Altin JG, Decker K, Bygrave FL. Possible involvement of eicosanoids in the zymosan and arachidonic-acid-induced oxygen uptake, glycogenolysis and $\mathrm{Ca}^{2+}$ mobilization in the perfused rat liver. Eur J Biochem 1987;165: 455-460.
36 Bilzer M, Jaeschke H, Vollmar AM, Paumgartner G, Gerbes AL: Prevention of Kupffer cell-induced oxidant injury in rat liver by atrial natriuretic peptide. Am J Physiol 1999;276: G1137-G1144.

37 Sies H: The use of perfusion of liver and other organs for the study of microsomal electrontransport and cytochrome P-450 systems. Methods Enzymol 1978;52:48-59.

38 Bilzer M, Paumgartner G, Gerbes AL: Prolonged antagonism of $\alpha_{1}$-adrenergic vasoconstriction in the rat liver by atrial natriuretic peptide. Gastroenterology 1995;108:803-811.

39 Bergmeyer HU: Methods of Enzymatic Analysis. New York, Academic Press, 1974.

40 Akerboom TPM, Sies H: Assay of glutathione, glutathione disulfide, and glutathione mixed disulfides in biological samples. Methods Enzymol 1981;77:373-382.

41 Tietze F: Enzymatic method for quantitative determination of nanogram amounts of total and oxidized glutathione. Ann Biochem 1969; 27:502-522.

42 Brass CA, Roberts TG: Hepatic free radical production after cold storage: Kupffer celldependent and -independent mechanisms in rats. Gastroenterology 1995;108:1167-1175.

43 Ookhtens MHK, Corvasce MC, Aw TY, Kaplowitz N: Sinusoidal efflux of glutathione in the perfused rat liver. J Clin Invest 1985;75: 258-265.

44 Hahn R, Wendel A, Flohe L: The fate of extracellular glutathione in the rat. Biochim Biophys Acta 1978;539:324-337.

45 Garcia-Ruiz C, Fernández-Checa JC, Kaplovitz $\mathrm{N}$ : Bidirectional mechanism of plasma membrane transport of reduced glutathione in intact rat hepatocytes and membrane vesicles. J Biol Chem 1992;267:22256-22264.

46 Jaeschke H: Enhanced sinusoidal glutathione efflux during endotoxin-induced oxidant stress in vivo. Am J Physiol 1992;263:G60-G68.

47 Liu P, Fisher MA, Farhood A, Smith CY, Jaeschke H: Beneficial effects of extracellular glutathione against endotoxin-induced liver injury during ischemia and reperfusion. Circ Shock 1994;43:64-70.

48 Imamura H, Sutto F, Brault A, Huet PM: Role of Kupffer cells in cold ischemia/reperfusion injury of rat liver. Gastroenterology 1995;109: 189-197.

49 Kukan M, Vajdova K, Horecky J, Nagyova A, Mehendale HM, Trnovec T: Effects of blockade of Kupffer cells by gadolinium chloride on hepatobiliary function in cold-ischemia-reperfusion injury of rat liver. Hepatology 1997;26: 1250-1257.

50 Aebi S, Assereto R, Lauterburg BH: High-dose intravenous glutathione in man: Pharmacokinetics and effects on cyst(e)ine in plasma and urine. Eur J Clin Invest 1991;21:103-110. 